Pena Justisia: Media Komunikasi dan Kajian Hukum
Vol. 17 No. 2, 2017, 59-69
Artikel Hasil Penelitian

\title{
Politik Hukum Imigrasi Nasional Pasca Terbentuknya Masyarakat Ekonomi ASEAN
}

\author{
${ }^{1}$ Inanda Agustina, ${ }^{2}$ Rukmana Amanwinata, ${ }^{3}$ Hernadi Affandi \\ ${ }^{1}$ Magister Kenotariatan Universitas Padjajaran, Indonesia \\ ${ }^{23}$ Fakultas Hukum Universitas Padjadjaran, Indonesia
}

Artikel Diterima:

21 November 2017

Artikel Disetujui:

6 Desember 2017

Artikel Diterbitkan:

15 Desember 2017

Korespondensi Penulis: inandarajagukguk@gmail.com

\begin{abstract}
The Law of Immigration in Indonesia regulate about immigration of foreigners to Indonesia mush accordance with the selective policy which includes their coming, presence, and going from the Indonesian territory. This should be based on Article 8 Of Law Number 6 of 2011 On Immigration wich give the benefit to Indonesia are permitted to immigrate, permitted to stay in Indonesia, and permitted to emigrate from Indonesia after they have fulfilled their obligation in Indonesia. Indonesia, state as an internasional community must follow the evolution. ASEAN Economy Community (AEC) is one of regional agreement which directs Indonsia from selective policy to open door policy. It is so contrary to national law in Indonesia especially to Immigration Law. This paper will answer some questions about how is the concept of selective policy on Law Number 6 of 2011 On Immigration as politics of national immigration law and how is the transformation of immigration policy from selective policy to open door policy after AEC as regional agreement and the profit for Indonesia.
\end{abstract}

Keywords: Selective policy, AEC, Politics of Law

\section{Abstrak}

Hukum Keimigrasian di Indonesia mengatur mengenai perlintasan orang asing yang masuk dan keluar Wilayah Negara Republik Indonesia yang menganut kebijakan selective policy. Hal tersebut dapat dilihat dalam Pasal 8 dan penjelasan Pasal 8 Undang-Undang Nomor 6 Tahun 2011 Tentang Keimigrasian yang mengatur mengenai persyaratan orang asing yang akan masuk wilayah Indonesia. Negara sebagai masyarakat internasional tidak dapat menutup mata terhadap perubahan jaman yang semakin canggih. MEA yang merupakan salah satu produk kesepakatan regional mengarahkan Indonesia untuk beralih pada open door policy. Hal tersebut jelas bertentangan dengan apa yang telah dianut oleh Hukum Nasional khususnya di bidang imigrasi. Tulisan ini menjawab pertanyaan tentang bagaimanakah konsep kebijakan selective policy dalam Undang-Undang Nomor 6 Tahun 2011 Tentang Keimigrasian sebagai politik hukum keimigrasian nasional dan bagaimanakah pergeseran kebijakan keimigrasian dari selective policy ke open door policy pasca perjanjian MEA serta apa keuntungannya bagi Indonesia.

Kata Kunci: Selective Policy, MEA, Politik Hukum 
60 Pena Justisia: Media Komunikasi dan Kajian Hukum

Vol. 17, No. 2, 2017

\section{PENDAHULUAN}

Suatu imigrasi adalah perpindahan manusia secara geografis, baik perorangan maupun berkelompok dari suatu tempat atau negara asal ke tempat atau negara lain dengan tujuan untuk menetap. ${ }^{1}$ Kemajuan teknologi dan transportasi yang semakin berkembang pesat, sangat memungkinkan hubungan antar negara berada dalam jangkauan yang cukup singkat. Motivasi dilakukannya imigrasi semakin meningkat didorong dengan adanya keinginan manusia untuk mendapatkan ketentraman dan kenikmatan tanpa batas di berbagai lingkungan.

Perpindahan atau perlintasan manusia yang masuk dan keluar suatu wilayah negara tidak dapat dihindari mengingat adanya kebutuhan hubungan antara negara-negara di dunia. Negara memberikan kebebasan bergerak bagi warganegara dalam kehidupan bersama namun juga membatasi ruang gerak tersebut karena dalam setiap negara terdapat kekuasaan tertinggi yang harus dihormati dan ditaati oleh warganegara wilayah tersebut dan warganegara wilayah lain yang berkaitan dengan kelangsungan kedaulatan wilayah negara. $^{2}$

Berdasarkan konsep tersebut, pemerintah suatu negara menetapkan ketentuan hukum terkait pengaturan dan pengawasan lalu lintas manusia yang masuk dan keluar dari wilayah tersebut. Dengan demikian, orang asing akan mendapatkan legalitas untuk melakukan perjalanan, melakukan kegiatan, dan/atau berada di negara lain secara sah. Ketentuan-ketentuan yang diatur oleh negara berkaitan dengan keleluasaan atau pembatasan bagi orang asing, maupun bagi warga negara sendiri untuk melakukan perjalanan antar negara disebut sebagai hukum keimigrasian. ${ }^{3}$

Hukum keimigrasian suatu negara dibentuk sedemikian rupa berdasarkan kebutuhan negara untuk menunjang prioritas program negara tersebut. Hal itu dapat dilihat dari kemungkinan

Ajat Sudrajat Havid, Formalitas Keimigrasian dalam Perspektif Sejarah Seri Keimigrasian, Direktorat Jenderal Imigrasi, Jakarta: 2008, hlm. 175

Ibid, hlm. 176

Ibid, hlm. 177 dibutuhkannya tenaga kerja asing, atau kemungkinan sedikitnya lapangan kerja yang tersedia, atau pula kemungkinan suatu negara yang menginginkan adanya keseimbangan rasial dalam negara. Dengan demikian, negara akan menetapkan seleksi terhadap orang asing tertentu yang akan mendapat izin masuk melalui perangkat operasional hukum keimigrasian.

Imigrasi di Indonesia dimulai dari masa sebelum kemerdekaan, kemudian masa sesudah kemerdekaan hingga sekarang. Keberadaan imigrasi di Indonesia sangat dibutuhkan dalam upaya menjamin kemanfaatan dan melindungi berbagai kepentingan nasional. Tugas dan wewenang keimigrasian seperti turut menjaga kesinambungan pembangunan kemajuan ilmu dan tekhnologi serta berkembangnya kerjasama regional dan internasional yang pada gilirannya mendorong meningkatnya arus manusia untuk masuk dan keluar wilayah Indonesia. ${ }^{4}$

Migrasi sebagai suatu gerak pindah manusia memasuki wilayah suatu negara dengan niat untuk mencari nafkah dan tinggal menetap di sana, defenisi mana telah sama disetujui dalam konfrensi Internasional tentang Emigrasi dan Imigrasi pada tahun 1924 di Roma. ${ }^{5}$ Setelah Indonesia merdeka, politik imigrasi diselaraskan dengan politik negara demi keselamatan dan kesejahteraan bangsa yang menjadikan imigrasi Indonesia memakai politik saringan (Selective Policy). Artinya harus teliti dengan perizinan orang asing yang masuk ke wilayah Indonesia, yakni hanya tenaga ahli yang dibutuhkan saja yang boleh masuk dan dibatasi baik jumlah maupun jangka waktu menetapnya. ${ }^{6}$ Hal tersebut tersirat dalam Pasal 8 ayat (1) dan (2) Undang-Undang Nomor 6 Tahun 2011 Tentang Keimigrasian yang menyatakan bahwa: 1) Setiap orang yang masuk atau keluar Wilayah Indonesia wajib memiliki Dokumen Perjalanan yang sah dan masih berlaku; 2) Setiap orang asing yang masuk Wilayah Indonesia wajib memiliki

4 M. Iman Santoso, Prespektif Imigrasi Dalam Pembangunan Ekonomi dan Ketahanan Nasional, Universitas Indonesia (UI-Press), Jakarta: 2004, hlm. 14 - 15

5 Direktorat Jenderal Imigrasi, Buku kenangan 50 tahun Imigrasi, hlm. 15

6 Ibid, hlm. 16 
visa yang sah dan masih berlaku, kecuali ditentukan lain berdasarkan Undang-Undang ini dan perjanjian internasional.

Indonesia yang merupakan anggota Association of Southest Asian Nation (selanjutnya akan disebut ASEAN) telah membentuk kesepakatankesepakatan dalam berbagai bidang termasuk bidang ekonomi dan hukum. Perkembangan kerjasama antara negara-negara ASEAN juga terus berkembang sampai pada akhirnya dibentuk Masyarakat Ekonomi ASEAN (selanjutnya akan disebut MEA) yang salah satu tujuannya adalah ASEAN sebagai pasar tunggal dan basis produksi internasional (single market and production base) dengan salah satu elemennya yaitu bebas tenaga kerja. ${ }^{7}$

Hal tersebut juga memunculkan wacana mengenai dibentuknya kebijakan bebas visa yang akan diterapkan negara-negara anggota ASEAN. ${ }^{8}$ Kemungkinan adanya kebijakan bebas visa demi peningkatan pembangunan ekonomi melalui MEA akan bertentangan dengan Pasal 8 Undang-Undang Nomor 6 Tahun 2011 Tentang Keimigrasian yang menganut konsep selective policy. Lebih lanjut, penelitian ini bertujuan untuk mengetahui dan memahami lebih lanjut mengenai politik hukum keimigrasian terkait kesepakatan MEA.

\section{PERMASALAHAN}

Berdasarkan uraian di atas, dirumuskan permasalahan dalam rumusan masalah sebagai berikut: Pertama, bagaimanakah konsep kebijakan selective policy dalam Undang-Undang Nomor 6 Tahun 2011 Tentang Keimigrasian sebagai politik hukum keimigrasian nasional, Kedua, bagaimanakah pergeseran kebijakan keimigrasian dari selective policy ke open door policy pasca perjanjian MEA serta apa keuntungannya bagi Indonesia.

\section{METODE PENELITIAN}

Metode pendekatan yang digunakan dalam penelitian ini adalah metode pendekatan yuridis

7 Kompas dikutip dari National Geographic Indonesia, "Pahami Masyarakat Eskonomi ASEAN (MEA) 2015", http://nationalgeographic.co.id/berita/2014/12/pahami -masyarakat-ekonomi-asean-mea-2015, diakses pada 9 Oktober 2017

8 Danang Prabowo, "Ekonom ASEAN Bahas MEA dan Kebijakan Bebas Visa”, 2016, Dikutip dari laman: https:// normatif dengan pendekatan perundang-undangan (statute approach). ${ }^{9}$ Penelitian ini menggunakan data sekunder yang berkaitan dengan politik hukum dan hukum keimigrasian yang terdiri dari: a) Bahan hukum primer diperoleh dengan cara inventarisasi terhadap peraturan perundang-undangan, Putusan Hakim Mahkamah Konstitusi, dokumen resmi dan literatur yang berkaitan dengan pokok permasalahan, untuk kemudian dikaji sebagai pedoman untuk penyusunan data. b) Bahan hukum sekunder diperoleh dengan cara studi pustaka terhadap hasil-hasil penelitian, literatur-literatur, makalah-makalah dalam seminar, artikel-artikel yang relevan dengan objek penelitian.

\section{PEMBAHASAN}

Kebijakan Selective Policy dalam UndangUndang Nomor 6 Tahun 2011 Tentang Keimigrasian sebagai Politik Hukum Keimigrasian Nasional

Hukum bukanlah suatu tujuan, melainkan hukum merupakan jembatan yang akan atau yang harus membawa kita kepada ide yang dicitacitakan. ${ }^{10}$ Oleh karena itu, Negara Indonesia harus mencari tau seperti apa cita-cita masyarakat Indonesia. Dengan demikian akan diketahui sistem hukum yang sesuai untuk mewujudkan cita-cita masyarakat Indonesia dan seperti apa politik hukum yang dapat menciptakan sistem hukum di Indonesia.

Politik hukum tidak dapat terlepas dari realita sosial dan tradisional yang terdapat di Negara Indonesia dan juga sebagai salah satu anggota masyarakat dunia, Indonesia tidak terlepas dari realita dan politik hukum internasional. Dengan demikian dapat kita ketahui bahwa untuk menentukan politik hukum nasional tidak hanya ditentukan oleh apa yang dicita-citakan atau tergantung pada kehendak pembentuk hukum, praktisi

ekbis.sindonews.com/read/1154059/34/ekonom-aseanbahas-mea-dan-kebijakan-bebas-visa-1478690786, diakses pada 18 November 2017

9 Peter Mahmud Marzuki, 2005, Penelitian Hukum, Jakarta: Kencana Prenada Media Group, hlm. 35

10 Sunaryati Hartono, 1976, Apakah The Rule of Law itu, Bandung: Alumni, hlm. 17 
atau para teoritis belaka, namun juga ditentukan oleh perkembangan hukum internasional. ${ }^{11}$

Politik hukum merupakan aktivitas memilih dan cara yang hendak dipakai untuk mencapai suatu tujuan sosial dan hukum tertentu dalam masyarakat. ${ }^{12}$ Maksudnya adalah untuk mencapai suatu tujuan negara, pemerintah yang berkuasa di dalamnya harus menemukan cara yang sesuai untuk dilakukan demi mencapai tujuan tersebut. Cara yang dilakukan negara untuk mencapai cita-cita bangsa dapat dilakukan melalui pembentukan kebijakan-kebijakan, peraturan perundang-undangan, maupun hubungan kerjasama dengan negara lain.

Hal-hal tersebut jelas membutuhkan strategi yang sistematis, terperinci dan mendasar. Aktivitas merumuskan dan menetapkan hukum, baik yang telah ada maupun yang akan dibentuk, politik hukum suatu negara diserahkan pada penyelenggara negara yang mempunyai otoritas legislasi dengan tetap memperhatikan nilai-nilai yang hidup dan berkembang di masyarakat. Kesemuanya itu diarahkan dalam rangka mencapai tujuan negara yang dicita-citakan. ${ }^{13}$

Politik hukum tersebut sejalan dengan teori politik hukum Padmo Wahyono yang memandang bahwa politik hukum sebagai kebijakan dasar yang menentukan arah, bentuk maupun isi dari hukum yang akan dibentuk. Politik hukum adalah kebijakan dasar penyelenggara negara dalam bidang hukum yang akan, sedang dan telah berlaku, yang bersumber dari nilai-nilai yang berlaku di masyarakat untuk mencapai tujuan negara yang dicita-citakan. ${ }^{14}$

Dengan demikian politik hukum suatu negara pasti akan berbeda dengan politik hukum negara lain. Hal tersebut dapat diketahui dari tujuan masing-masing negara di dunia yang pasti berbeda, dengan latar belakang negara yang berbeda, pandangan hidup yang berbeda, sosial budaya tiap

11 Sunaryati Hartono, 1991. Politik Hukum Menuju Satu Sistem Hukum Naisonal, Bandung: Alumni, hlm. 1

12 Satjipto Raharjo, 2000, Ilmu Hukum, Bandung: Citra Aditya Bakti, hlm. 35

13 Frans Magnis Suseno, 1994, Etika Politik:Prinsip-Prinsip Dasar Kenegaraan Modern, Gramedia Pustaka Utama, Jakarta, hlm: 310-314 negara serta nilai-nilai yang tumbuh dan berkembang di tengah masyarakat negara tersebut.

Dasar pembentukan Negara Indonesia tidak terlepas dari ingatan akan masa penjajahan Hindia Belanda. Sebagaimana sistem penjajahan pada umumnya, Belanda pada masa itu berusaha untuk mendapatkan keuntungan sebesar-besarnya dari tanah jajahan Indonesia. Seluruh potensi kekayaan alam Indonesia diolah dan digali semaksimal mungkin demi kepentingan Negara Belanda dan orang-orang Belanda di Indonesia.

Kesempatan penanaman modal asing dibuka selebar-lebarnya oleh pemerintahan Hindia Belanda pada masa itu untuk memenuhi kebutuhan negara-negara barat akan komoditi ekspor, seperti karet, teh, kopi, tembakau, gula, lada, timah, dan pertambangan lainnya, yang ketika itu menjadi sasaran pokok investasi. ${ }^{15}$ Investasi-investasi tersebut membutuhkan banyak buruh yang murah sehingga selain buruh dari Indonesia, didatangkan pula banyak buruh asing, khususnya dari Cina.

Orang asing diberikan kelonggaran dan keleluasan di lapangan ekonomi, yang pada saat itu dipandang sekunder yang menimbulkan kemiskinan dan kebodohan rakyat Indonesia karena tidak bisa bersaing dengan orang asing yang terkenal ulet. Usaha mendatangkan buruh asing tersebut dilaksanakan secara aktif dan pula memberikan uang panjar untuk ongkos jalan dan jaminan hidup yang layak kepada buruh asing. Imigranimigran tersebut juga diberikan akses pelayaran oleh perusahaan pelayaran Belanda yang membuka jalur pelayaran antara Jawa, Cina dan Jepang. ${ }^{16}$

Politik keimigrasian saat itu mendukung aktifitas tersebut, sebagaimana tampak dalam peraturan-peraturan keimigrasian yang memungkinkan orang asing datang secara masal untuk tujuan menetap. Peraturan-peraturan tersebut dibuat tidak untuk melindungi kepentingan Bangsa

14 Padmo Wahyono, 1986, Indonesia Negara Berdasatkan atas hukum, Cet. II, Jakarta: Ghalia Indonesia, hlm. 160

15 Ajat Sudrajat Havid, Loc. Cit. hlm. 179

16 Ibid. 
Indonesia, namun sesuai dengan tujuan negara pada saat itu untuk memberikan keuntungan yang besar bagi negara Belanda dan bukan berdasarkan kepentingan Bangsa Indonesia. ${ }^{17}$

Beranjak dari pengalaman tersebut, masyarakat yang dicita-citakan Bangsa Indonesia dapat dilihat dalam Pembukaan Undang-Undang Dasar Republik Indonesia Tahun 1945 pada alinea keempat yang menyatakan bahwa tujuan pembentukan Negara Republik Indonesia, antara lain : “... melindungi segenap Bangsa Indonesia dan seluruh tumpah darah Indonesia, dan untuk memajukan kesejahteraan umum, mencerdaskan kehidupan bangsa ..." Dari kutipan tersebut, kiranya dapat diketahui bahwa tujuan pembentukan Negara Indonesia antara lain adalah untuk menjaga stabilitas keamanan negara serta seluruh kegiatan pemerintahan diarahkan untuk mencapai kemakmuran rakyat, secara materil dan spiritual. ${ }^{18}$

Dengan demikian keberadaan orang asing yang menjadi beban atau menghambat peningkatan kesejahteraan warganegara Indonesia, harus ditolak masuk atau dikeluarkan dari wilayah Indonesia. Oleh karena itu, setiap orang asing yang akan memasuki wilayah Indonesia harus dilakukan penyaringan (selection), yaitu dengan menetapkan persyaratan tertentu yang harus dipenuhi oleh orang asing tersebut agar dapat diberikan izin untuk tinggal di Indonesia.

Politik keimigrasian tersebut ditegaskan secara formal dalam penjelasan Undang-undang No. 8/Drt/1995, bahwa: Negara kita tidak lagi menjalankan opendeur atau massale politik terhadap pendatang orang asing itu, akan tetapi politik saringan atau selectieve politiek yang berdasarkan atas lain kepentingan, pendirian dan tujuan". ${ }^{19}$ Secara konsisten, politik saringan tersebut dilaksanakan sampai dibentuknya UndangUndang Nomor 6 Tahun 2011 Tentang Keimigrasian. Kebijakan selective policy dapat dilihat pula dalam Pasal 8 Undang-Undang Nomor 6 Tahun 2011 Tentang Keimigrasian yang menyatakan bahwa: 1) Setiap orang yang masuk atau keluar Wilayah Indonesia wajib memiliki Dokumen

7 Ibid, hlm. 184

18 Ibid.
Perjalanan yang sah dan masih berlaku; 2) Setiap orang asing yang masuk Wilayah Indonesia wajib memiliki visa yang sah dan masih berlaku, kecuali ditentukan lain berdasarkan Undang-Undang ini dan perjanjian internasional.

Penjelasan Pasal 8 Undang-Undang Nomor 6 Tahun 2011 Tentang Keimigrasian, menyatakan bahwa: Yang dimaksud dengan "dokumen perjalanan yang sah dan masih berlaku" adalah dokumen perjalanan yang dikeluarkan oleh pejabat yang berwenang dan masih berlaku sekurang-kurangnya selama 6 (enam) bulan sebelum masa berlakunya berakhir.

Adanya kebijakan selektif tersebut, berarti mengatur orang asing ke Indonesia, yang mencakup masuk, berada, serta keluarnya orang asing tersebut dari wilayah Indonesia. Berdasarkan prinsip tersebut, hanya orang asing yang menguntungkan Indonesia, yang dapat diberi ijin masuk, ijin berada di Indonesia, sedangkan untuk ijin keluar diberikan setelah orang asing tersebut menyelesaikan kewajibannya di Indonesia.

Kebijakan selektif tersebut dilakukan dengan menerapkan sistem pemeriksaan dokumen sebagaimana diatur dalam Pasal 9 Undang-Undang Keimigrasian yang menyatakan: (1) Setiap orang yang masuk atau keluar Wilayah Indonesia wajib melalui pemeriksaan yang dilakukan oleh Pejabat Imigrasi di Tempat Pemeriksaan Imigrasi; (2) Pemeriksaan sebagaimana dimaksud pada ayat (1) meliputi pemeriksaan Dokumen Perjalanan dan/atau identitas diri yang sah; (3) Dalam hal terdapat keraguan atas keabsahan Dokumen Perjalanan dan/atau identitas diri seseorang, Pejabat Imigrasi berwenang untuk melakukan penggeledahan terhadap badan dan barang bawaan dan dapat dilanjutkan dengan proses penyelidikan Keimigrasian.

Pada dasarnya fungsi dan peran keimigrasian bersifat universal, yaitu melaksanakan lalu lintas orang masuk atau keluar wilayah suatu negara. Hal tersebut dilaksanakan berdasarkan suatu politik imigrasi yaitu kebijakan negara yang telah ditetapkan digariskan oleh pemerintah se-

19 Ibid, hlm. 185 
suai dengan ketentuan hukum, sesuai dengan peraturan perundang-undangan yang berlaku. Secara operasional, peran keimigrasian di Indonesia selalu mengandung tiga fungsi, yaitu: ${ }^{20}$

Pertama, fungsi pelayanan masyarakat untuk menyelenggarakan pemerintahan atau administrasi negara. Jasa keimigrasian diberikan oleh instansi imigrasi kepada warga negara sendiri maupun warga negara asing. Pelayanan terhadap warga negara Indonesia dapat berupa: memberikan paspor/SPLP/Pas Lintas Batas dan memberikan tanda bertolak/masuk. Sedangkan pelayanan terhadap warga negara asing dapat beurpa: memberikan dokumen imigrasi, perpanjangan izin tinggal, pemberian izin masuk kembali atau izin bertolak, memberikan tanda bertolak atau masuk.

Kedua, fungsi penegakan hukum oleh keimigrasian ditegakkan kepada setiap orang yang berada di wilayah Indonesia, baik Warga Negara Indonesia maupun Warga Negara Asing. Sehingga apabila terjadi pelanggaran administratif, pihak imigrasi akan memberikan sanksi administratif. Begitu pula dengan hal-hal yang berkaitan dengan kasus-kasus yang bersifat pidana keimigrasian, akan diproses secara pro yustisia di pengadilan.

Ketiga, fungsi kemanan yang mana imigrasi merupakan institusi pertama dan terakhir yang menyaring kedatangan dan keberangkatan orang asing ke dan dari wilayah Indonesia. Imigrasi bekerjasama dengan aparatur keamanan negara lainnya khususnya dalam penegakan hukum keimigrasian serta melakukan operasi intelijen keimigrasian bagi kepentingan ketahanan dan keamanan negara.

Politik hukum keimigrasian suatu negara, mencerminkan kedaulatan negara, kepentingan negara, sejalan dengan aspirasi dan kepentingan masyarakat. ${ }^{21}$ Kebijakan selektif mengatur bahwa orang asing yang akan masuk ke Indonesia harus melakukan serangkaian pemeriksaan guna mengetahui kepentingan apa yang dilakukan orang asing tersebut selama di Indonesia. Hal tersebut

20 Ramadhan K. H., \& Abrar Yusra, 2005, Lintas Sejarah Imigrasi Indonesia, Jakarta: Direktorat Jenderal Imigrasi, hlm. 14 dilakukan guna mewujudkan kebijakan selektif yang mana hanya orang asing yang menguntungkan bagi Indonesia yang dapat masuk ke Indonesia. Orang asing yang akan menjadi beban atau memungkinkan terjadinya ketidaksejahteraan di tengah masyarakat Indonesia, tidak akan mendapatkan ijin masuk ke Negara Indonesia.

Kebijakan selektif itu diterapkan Indonesia sebagai politik hukum keimigrasian nasional guna menjaga moral dan kepentingan masyarakat, serta ketertiban umum dan keamanan nasional. ${ }^{22} \mathrm{Me}-$ lalui kebijakan selektif, Indonesia dapat pula meminimalisir atau mencegah masuknya orangorang asing yang berniat mengganggu keamanan Negara, baik dengan melakukan penyelundupan hukum, perdagangan yang bertentangan dengan peraturan perundang-undangan, maupun sikapsikap yang tidak sesuai dengan nilai-nilai yang dianut Bangsa Indonesia.

Peran Masyarakat Ekonomi ASEAN (MEA) dalam Perubahan Kebijakan Keimigrasian Nasional

Batas-batas wilayah suatu negara sering kali dilewati manusia-manusia dengan motivasi yang berbeda-beda, yang juga merupakan suatu fenomena global yang dinamis. Perkembangan arus lalu lintas manusia secara global selalu mengalami peningkatan, baik dari segi jumlah, permasalahannya yang kompleks, maupun dampak-dampak ekonomi, sosial budaya, dan keamanan yang ditimbulkan dari pergerakan tersebut yang secara langsung memberikan pengaruh terhadap perkembangan tugas dan fungsi keimigrasian.

Peran dan fungsi imigrasi dalam menunjang kebijakan pemerintah Indonesia di berbagai lembaga pemerintah dan secara internasional dapat pula dilakukan dengan pemetaan perubahan tren dan pola migrasi internasional, penguatan fungsi intelijen keimigrasian, penegakan hukum keimigrasian, juga penerapan dan pengembangan teknologi informasi serta perluasan kerjasama in-

21 Ibid, hlm. 15

22 A-bdullah Sfahriful, 2005, Memperkenalkan hukum Keimigrasian, Jakarta: Grafika Indonesia, hlm. 45 
ternasional keimigrasian dalam menjaga kedaulatan negara.

Salah satu isu strategis dalam migrasi internasional adalah pembentukan integrasi kawasan, seperti ASEAN, APEC, BIMP-EAGA, Bali Process, IMT-GT, dan lain sebagainya sebagai tahapan dalam integrasi kawasan, yang menjadikan batasbatas wilayah antar negara seakan menjadi semakin abstrak, dan keterhubungan antar negara yang berada dalam suatu kawasan menjadi semakin kuat. $^{23}$

Pada era globalisasi saat ini, Indonesia harus siap menghadapi Masyarakat Ekonomi ASEAN dan berbagai permasalahan yang mungkin akan timbul di kemudian hari. MEA merupakan salah satu kesepakatan yang dibuat oleh negara-negara yang termasuk dalam ASEAN sebagai akibat suatu kerjasama regional.

Terbentuknya MEA berawal dari kesepakatan para pemimpin ASEAN dalam Konferensi Tingkat Tinggi (KTT) pada Desember 1997 di Kuala Lumpur, Malaysia. Kesepakatan ini bertujuan meningkatkan daya saing ASEAN serta bisa menyaingi Tiongkok dan India untuk menarik investasi asing. Modal asing dibutuhkan untuk meningkatkan lapangan pekerjaan dan kesejahteraan warga ASEAN. Pada KTT selanjutnya yang berlangsung di Bali Oktober 2003, petinggi ASEAN mendeklarasikan bahwa pembentukan MEA pada tahun 2015.

Tujuan utama MEA 2015 yang ingin menghilangkan secara signifikan hambatan-hambatan kegiatan ekonomi lintas kawasan tersebut, diimplementasikan melalui 4 pilar utama, yaitu: ${ }^{24}$

Pertama, ASEAN sebagai pasar tunggal dan basis produksi internasional (single market and production base) dengan elemen: aliran bebas barang, jasa, bebas investasi, tenaga kerja terdidik dan aliran modal yang lebih bebas.

23 Sri S, 2016, Perubahan Paradigma Keimigrasian Dunia dan Pengaruhnya pada Politik Hukum Keimigrasian Indonesia Dalam Rangka Penegakkan Kedaulatan NKRI, Dikutip dari laman:https://berantasnews.com/perubahan-paradigmakeimigrasian-dunia-dan-pengaruhnya-pada-politikhukum-keimigrasian-indonesia-dalam-rangkapenegakkan-kedaulatan-nkri/) diakses pada tanggal 16 November 2011
Kedua, ASEAN sebagai kawasan dengan daya saing ekonomi yang tinggi (competitive economic region), dengan elemen: peraturan kompetisi, perlindungan konsumen, hak atas kekayaan intelektual, pengembangan infrastruktur, perpajakan, dan e-commerce.

Ketiga, ASEAN sebagai kawasan dengan pengembangan ekonomi yang merata (equitable economic development) dengan elemen: pengembangan usaha kecil dan menengah, dan prakarsa integrasi ASEAN untuk negara-negara CMLV (Cambodia, Myanmar, Laos, dan Vietnam) dan

Keempat, ASEAN sebagai kawasan yang terintegrasi secara penuh dengan perekonomian global (integration into the global economy) dengan elemen: pendekatan yang koheren dalam hubungan ekonomi di luar kawasan, dan meningkatkan peran serta dalam jejaring produksi global.

Terkait fungsi keimigrasian, integrasi kawasan berkaitan dengan manajemen keimigrasian sehingga Indonesia diharapkan mampu untuk menciptakan keseimbangan antara pemberian kemudahan-kemudahan kepada orang-orang yang melakukan perlintasan wilayah dengan peningkatan pengawasan terhadap perlintasan orang di dalam wilayah kawasan tersebut. Tujuan utama MEA sendiri merupakan bentuk dari integrasi ekonomi negara-negara Asia Tenggara, yang mana untuk bisa sampai ke tujuan ASEAN dalam empat pilar sebagaimana telah disebutkan di atas tadi, maka salah satu cara yang dapat dilakukan adalah dengan menerapkan bebas visa.

Kebijakan bebas visa khususnya berkaitan dengan diterapkannya kebijakan MEA dan bebas tenaga kerja antarnegara ASEAN, sementara ini masih berlaku pada delapan provinsi di Indonesia. ${ }^{25}$ Demikian halnya menyangkut pemberian kebijakan bebas VISA kunjungan kepada turis dari sejumlah negara tertentu ke Indonesia. Antara

24 ASEAN Economic Community, Dikutip dari laman: http://apindo.or.id/id/fta/asean-economiccommunity/latar-belakang), diakses pada 16 November 2017

25 Evarianus Supar, Imigrasi siapkan SDM hadapi MEA dan bebas visa kunjungan, 2016, Dikutip dari laman: http://m.antarapapua.com/berita/454499/imigrasisiapkan-sdm-hadapi-mea-dan-bebas-visa-kunjungan diakses pada tanggal 16 November 2017 
negara-negara yang tergabung dalam MEA, bebas keluar masuk wilayah Indonesia, tanpa ada hambatan-hambatan khususnya dalam bidang aturan, dimana secara lebih khusus keberadaan MEA adalah hampir sama dengan keberadaan AFTA (ASEAN Free Trade Area) yang hadir untuk menyaingi China dan peningkatan investasi negaranegara Asia Tenggara. ${ }^{26}$

Sebelum terbentuknya MEA yang berujung pada akan dikeluarkannya kebijakan bebas visa, politik hukum keimigrasian telah mengatur kebijakan tersebut, yaitu dalam Keputusan Menteri Kehakiman No. M.01-12.01.02 Tahun 1993 Tentang Bebas Visa Kunjungan Singkat (selanjutnya akan disebut BVKS), yang pelaksanaan teknisnya meliputi: a) Kunjungan wisata; b) Kunjungan sosial budaya; c) Kunjungan usaha; d) Kunjungan wisata adalah perjalanan mengunjungi Indonesia untuk berlibur, menikmati objek-objek wisata dan lain-lain; e) Kunjungan sosial budaya adalah kunjungan dalam rangka mengunjungi keluarga, melakukan penelitian dan kunjungan yang bersifat sosial budaya, sedangkan kunjungan usaha adalah kunjungan dalam rangka membina hubungan bisnis, pembicaraan bisnis dan penjajakan memperluas usaha bisnis di Indonesia. ${ }^{27}$

Hal tersebut diatur pemerintah dengan harapan akan memberikan manfaat dan pengaruh positif terhadap pembangunan nasinal juga meningkatnya pemasukan negara. Namun ternyata banyak orang orang asing yang menyalahgunakan BVKS untuk kepentingan lain seperti bekerja, hubungan masyarakat dan lain-lain, bukannya digunakan untuk berwisata yang jelas merugikan negara. Penyalahgunaan tersebut juga sebenarnya tidak bisa murni dilimpahkan kepada orang asing karena pemerintah sendiri tidak mengawasi dengan tegas melalui pengumpulan data pemegang BVKS. Sehingga penyalahgunaan BVKS tidak sulit untuk dilakukan orang asing yang masuk ke wilayah Indonesia.

Pemerintah Indonesia pada akhirnya memberikan bebas visa dengan prinsip resiprokal, atau

26 Yasmin Sungkar, 2009, Pola Integrasi Ekonomi Di Kawasan Asia Timur, Jakarta: Departemen Luar Negeri Republik Indonesia, hlm. 26 prinsip timbal balik sebagaimana diatur dalam Keputusan Presiden No. 18 Tahun 2003. Hanya apabila suatu negara memberlakukan bebas visa terhadap Warga Negara Indonesia yang datang ke negara itu, maka Indonesia akan memberlakukan hal yang sama terhadap warga negara tersebut. ${ }^{28}$ Hal tersebut diterapkan pemerintah guna menyeimbangkan kebijakan negara-negara lain dengan Indonesia sendiri. Dengan demikian Indonesia tidak akan dirugikan oleh orang-orang asing dari negara lain yang menyalahgunakan kebijakan bebas visa demi keuntungan pribadi atau negaranya.

Kebijakan bebas visa yang sudah atau akan dilakukan berkaitan dengan kebijakan MEA dan bebas tenaga kerja, diatur sedemikian rupa oleh pemerintah guna mendapatkan manfaat yang lebih besar. Namun kebijakan bebas visa tersebut nyatanya bertentangan dengan sistem selective policy yang terkandung dalam Pasal 8 UndangUndang Nomor 6 Tahun 2011 Tentang Keimigrasian. Dampak terhadap politik hukum kebijakan keimigrasian nasional yang terjadi akibat kesepakatan MEA yang akhirnya akan memunculkan kebijakan bebas visa, membuka peluang terjadinya sistem terbuka (open door policy).

Dengan demikian dapat dikatakan politik hukum keimigrasian yang bersifat open door policy dilaksanakan guna mencapai cita-cita bangsa Indonesia yang dipengaruhi oleh hubungan internasional antarnegara dalam hal ini ASEAN yang menyepakati MEA, sedangkan politik hukum keimigrasian yang bersifat selective policy dilaksanakan guna kepentingan nasional Indonesia.

Open door policy merupakan suatu perubahan dari politik hukum keimigrasian yang tadinya bersifat selektif menjadi terbuka. Politik hukum keimigrasian yang dilakukan melalui selective policy mengharuskan adanya persyaratan tertentu yang harus dipenuhi, seperti memiliki dokumen perjalanan yang sah dan berlaku, bagi orang asing yang akan memasuki Wilayah Indonesia baik untuk menetapkan, berwisata, atupun kepentingan lainnya yang jelas tidak bertentangan

27 Lukman Bratamidjaja, 2002, Aspek Ilmu Perundangundangan BVKS Bagian I, Jakarta: Direktorat Jendral Imigrasi, hlm. 25

28 Ramadhan K.H., Abrar Yusra, Op. Cit. hlm. 188 
dengan kepentingan masyarakat Indonesia. Sedangkan open door policy tidak mengharuskan adanya hal-hal sebagaimana tersebut di atas. Tanpa visa atau dokumen perjalanan yang sah dan berlaku, orang asing dapat masuk ke Wilayah Indonesia.

Kebijakan politik hukum keimigrasian dalam menghadapi MEA yang memungkinkan open door policy harus memperhatikan secara seimbang antara kepentingan nasional dan kepentingan global. Untuk menjamin keseimbangan tersebut, dalam melaksanakan fungsi keimigrasian perlu diperhatikan beberapa prinsip berikut :29

Pertama, prinsip bahwa Indonesia adalah non immigrant state. Prinsip ini bermaksud membatasi semaksimal mungkin pertambahan penduduk melalui proses kewarganegaraan yang berpangkal pada hak-hak keimigrasian.

Kedua, Prinsip Selective Policy. Fasilitas keimigrasian terhadap orang asing hendaknya dengan sungguh-sungguh memperhatikan kemanfaatannya bagi usaha-usaha pembangunan dan usaha mewujudkan kesejahteraan bagi bangsa Indonesia.

Ketiga, Prinsip keseimbangan antara welfare (prosperity) dan security. Prinsip keseimbangan antara pengawasan, pengendalian dan pelayanan. Orang asing adalah tamu, dan karena itu harus diperlakukan secara layak baik dalam hubungan yang bersifat hukum maupun dalam hubungan sosial. Namun demikian hal tersebut harus tidak mengurangi kewajiban tamu untuk berlaku wajar sesuai dengan kepentingannya, sehingga kepentingan security bagi masyarakat dan negara senantiasa terlaksana secara wajar.

Keempat, Prinsip the right of movement. Setiap orang yang berada dalam wilayah Negara Republik Indonesia dijamin dan dilindungi hak-haknya untuk melakukan perjalanan termasuk hak untuk berkomunikasi, sepanjang tidak membahayakan diri atau kepentingan negara yang khusus.

Kelima,Prinsip keimigrasian sebagai bagian dari penyelenggaraan administrasi negara. Pada prinsip ini keimigrasian harus senantiasa berjalan di atas asas-asas umum penyelenggaraan negara yang layak (general principle of good administration). Setiap orang yang berada dalam wilayah Negara Republik Indonesia dijamin dan dilindungi hak-haknya untuk melakukan perjalanan termasuk hak untuk berkomunikasi, sepanjang tidak membahayakan diri atau kepentingan Negara yang khusus.

Keimigrasian Indonesia bertujuan untuk kesejahteraan warga Indonesia dan warga negara asing khususnya sebagaimana dituangkan dalam Konsidren Undang-undang nomor 6 Tahun 2011 Tentang Keimigrasian yang menerangkan bahwa keimigrasian merupakan bagian dari perwujudan pelaksanaan penegakan kedaulatan atas wilayah Indonesia dalam rangka menjaga ketertiban kehidupan berbangsa dan bernegara menuju masyarakat yang adil dan makmur berdasarkan Pancasila dan Undang-Undang Dasar Negara Republik Indonesia Tahun 1945.

Diterapkannya open door policy sebagai dampak adanya MEA kaitannya dengan bebas visa memberikan keuntungan dan kerugian bagi Indonesia. Bebas visa menjadi daya tarik tersendiri bagi orang asing yang akan memasuki wilayah Indonesia. Mereka akan merasa diuntungkan dengan tidak perlu menghabiskan waktu dalam pembuatan visa jika ingin memasuki wilayah Indonesia. Di sisi lain, indonesia juga mendapat keuntungan dari banyaknya wisatawan asing yang datang ke Indonesia sehingga akan meningkatkan wisatawan asing dan tenaga kerja asing. Namun juga kelemahan dari diterapkannya open door policy dapat memberi dampak negatif bagi Indonesia karena dimungkinkan adanya penyalahgunaan oleh orang asing terhadap bebas visa yang diberikan oleh Indonesia. Sama halnya seperti pada tahun 1993, banyak terjadi penyalahgunaan terhadap BVKS yang diberikan pemerintah Indonesia bagi orang asing.

Perkembangan global saat ini jelas mendorong peningkatan mobilitas penduduk dunia. Hal tersebut menimbulkan berbagai dampak, baik yang menguntungkan maupun yang merugikan

29 Bagir Manan, 2000, Hukum Keimigrasian dalam Sistem Hukum Nasional, Jakarta: Ghalia Indonesia, hlm. 87 
bagi kepentingan dan kehidupan Bangsa dan Negara Republik Indonesia, sehingga diperlukan peraturan perundang-undangan yang menjamin kepastian hukum yang sejalan dengan penghormatan, pelindungan, dan pemajuan hak asasi manusia khususnya di Indonesia sendiri.

\section{PENUTUP}

\section{Kesimpulan}

Kebijakan selective policy dapat dilihat dalam Pasal 8 dan penjelasan Pasal 8 Undang-Undang Nomor 6 Tahun 2011 Tentang Keimigrasian yang mengatur mengenai persyaratan orang asing yang akan masuk wilayah Indonesia. Kebijakan selektif tersebut mengatur orang asing ke Indonesia, yang mencakup masuk, berada, serta keluarnya orang asing tersebut dari wilayah Indonesia. Berdasarkan prinsip tersebut, hanya orang asing yang menguntungkan Indonesia, yang dapat diberi ijin masuk, ijin berada di Indonesia, sedangkan untuk ijin keluar diberikan setelah orang asing tersebut menyelesaikan kewajibannya di Indonesia.

MEA yang merupakan produk ASEAN berdampak pada politik hukum keimigrasian yang menganut selective policy karena untuk mencapai salah satu tujuan MEA, dilakukan dengan cara bebas visa yang membuka peluang dianutnya open door policy di Indonesia. Politik hukum keimigrasian yang dilakukan melalui selective policy mengharuskan adanya persyaratan tertentu yang harus dipenuhi, seperti memiliki dokumen perjalanan yang sah dan berlaku, bagi orang asing yang akan memasuki Wilayah Indonesia baik untuk menetapkan, berwisata, atupun kepentingan lainnya yang jelas tidak bertentangan dengan kepentingan masyarakat Indonesia. Sedangkan open door policy tidak mengharuskan adanya hal-hal sebagaimana tersebut di atas. Tanpa visa atau dokumen perjalanan yang sah dan berlaku, orang asing dapat masuk ke Wilayah Indonesia.

\section{Saran}

Open door policy kaitannya dengan bebas visa sebagai dampak dari MEA yang bertujuan meningkatkan perekonomian nasional, mengharuskan Indonesia lebih tegas lagi dalam melakukan pengawasan/pengontrolan meliputi seluruh rang- kaian kegiatan keluar masuknya orang asing ke wilayah Indonesia dan keberadaan orang asing di Indonesia, telah sesuai atau tidak dengan ketentuan keimigrasian yang berlaku.

\section{DAFTAR PUSTAKA}

Bratamidjaja, Lukman. 2002. Aspek Ilmu Perundang-undangan BVKS Bagian I. Jakarta: Direktorat Jendral Imigrasi;

Hartono, Sunaryati. 1991. Politik Hukum Menuju Satu Sistem Hukum Naisonal. Bandung: Alumni;

Iman M. Santoso. 2004. Prespektif Imigrasi Dalam Pembangunan Ekonomi dan Ketahanan Nasional. Jakarta: Universitas Indonesia (UI-Press);

K. H. Ramadhan \& Abrar, Yusra. 2005. Lintas Sejarah Imigrasi Indonesia. Jakarta: Direktorat Jenderal Imigrasi;

Magnis, Frans Suseno. 1994. Etika Politik:PrinsipPrinsip Dasar Kenegaraan Modern. Jakarta: Gramedia Pustaka Utama.

Manan, Bagir. 2000. Hukum Keimigrasian dalam System Hukum Nasional. Jakarta: Ghalia Indonesia;

Raharjo, Satjipto. 2000. Ilmu Hukum. Bandung: Citra Aditya Bakti.;

Sfahriful, Abdullah. 2005. Memperkenalkan hukum Keimigrasian. Jakarta: Grafika Indonesia.;

Sudrajat, Ajat Havid. 2008. Formalitas Keimigrasian dalam Perspektif Sejarah Seri Keimigrasian. Jakarta: Direktorat Jenderal Imigrasi.

Sungkar, Yasmin. 2009. Pola Integrasi Ekonomi Di Kawasan Asia Timur. Jakarta: Departemen Luar Negeri Republik Indonesia;

Wahyono, Padmo. 1986. Indonesia Negara Berdasarkan atas hukum. Cet. II. Jakarta: Ghalia Indonesia;

"ASEAN Economic Community". Dikutip dari laman: http://apindo.or.id/id/fta/aseaneconomic-community/latar-belakang)

Sri S. Perubahan Paradigma Keimigrasian Dunia dan Pengaruhnya pada Politik Hukum Keimigrasian Indonesia Dalam Rangka Penegakkan Kedaulatan NKRI. Diktup dari laman:https://berantasnews.com/perubaha n-paradigma-keimigrasian-dunia-danpengaruhnya-pada-politik-hukum- 
keimigrasian-indonesia-dalam-rangkapenegakkan-kedaulatan-nkri/)

"Pahami Masyarakat Eskonomi ASEAN (MEA) 2015". Dikutip dari laman: http://national geographic.co.id/berita/2014/12/pahamimasyarakat-ekonomi-asean-mea-2015

Evarianus, Supar. 2016. "Imigrasi siapkan SDM hadapi MEA dan bebas visa kunjungan" Dikutip dari laman: (http://m.antarapapua .com/berita/454499/imigrasi-siapkansdm-hadapi-mea-dan-bebas-visakunjungan

Prabowo, Danang. 2016. "Ekonom ASEAN Bahas MEA dan Kebijakan Bebas Visa". Dikutip dari laman: https://ekbis.sindonews.com/ read/1154059/34/ekonom-asean-bahasmea-dan-kebijakan-bebas-visa1478690786 